супругов, родителей и детей закладываются основы норм и правил нравственности, формируются мировоззрение, ценностные ориентации индивида. В зависимости от того, как складываются эти отношения и общения, который воспитательный потенциал имеет семья, формируется личность ребенка.

В Российском обществе современного типа по-прежнему преобладают не только классический состав семьи, но количество детей. Во многом на то, сколько поколений сосуществуют в одном доме, влияют материальные возможности, но тенденция к отселению молодой пары от родителей становится все более популярной.

$$
* * *
$$

1. Артамонова, А.В. Сожительства без регистрации в России / А.В. Артамонова, Е.С. Митрофанова // Демоскоп Weekly. 2016. № 671-672. [Электронный pecypc]. - URL: http:// www. demoscope.ru/weekly/ 2016/0671/demoscope671 .pdf

2. Ворожейкин, Е.М. Брак и семья в СССР / Е.М. Ворожейкин. - М.: Знание, 2015. - 152 с.

3. Гофман, А.Б. 7 лекций по истории социологии / А.Б. Гофман. - М.: Университет, 2017. - 216 с.

4. Нечаева, А. М. Брак, семья, закон / А.М. Нечаева. - М.: Наука, 2015. - 144 с.

5. Оганян, К.М. Общая социология: учебное пособие / К.М. Оганян. - М.: НИЦ ИНФРА-М, 2015. $236 \mathrm{c}$.

6. Паниотова, Т.С. Общая социология: учебное пособие / Т.С. Паниотова. - М.: КноРус, 2015. - 288 с.

7. Семенова Дом - зеркало судьбы. Как приворожить удачу для всей семьи / Семенова, Анастасия. СПб: Невский проспект, 2017. - 157 с.

8. Семья в современном обществе [Электронный pecypc]. - URL: https://xn----dtbebvqepcbbtq4r.xn-p1ai/blog/semya-v-sovremennom-obshhestve

\title{
Полякова О.O.
}

\section{Место сайтов знакомств в добрачном поведении населения}

ФГБОУ ВО «НИИ Мордовский государственный университет им. Н.П. Огарева» (Россия, Саранск)

doi:10.18411/spc-01-11-2020-04

idsp: sciencepublic-01-11-2020-04

\section{Аннотация}

В статье рассмотрены особенности сайтов знакомств как формы добрачного поведения населения. В современном мире сайты знакомств включены в брачносемейное поведение населения благодаря повсеместному распространению и своим функциям: возможностям выбора партнера, накопления первичных впечатлений, проектирование будущей жизни.

Ключевые слова: сайт знакомств, семья, брачное поведение, добрачное поведение, знакомство, брак.

\section{Abstract}

The article discusses the features of Dating sites as a form of premarital behavior of the population. In the modern world, Dating sites are included in the marital and family behavior of the population due to their ubiquity and their functions: the ability to choose a partner, accumulate primary impressions, and design a future life. marriage.

Keywords: Dating sirvice, family, marital behavior, premarital behavior, Dating,

Брачно-семейные отношения всегда трансформируются вместе с общими социокультурными изменениями. Исследователи отмечают увеличение числа сожительств и внебрачных рождений, повышение возраста вступления в брак, а также отказ от брака и распространение феномена одиночества как одобряемого стиля жизни. В этой ситуации 
все более актуальным является анализ новых моделей семейных отношений, форм брачного поведения и особенностей добрачного поведения.

С развитием информационных технологий все большее людей разного возраста используют для знакомства и поиска партнера и супруга сайты знакомств (Datingсервис). Виртуальные службы знакомств (сайты знакомств) - интернет_серверы, предоставляющие пользователям Интернета услуги по виртуальному общению с другими пользователями.

Цель данной статьи - рассмотреть место сайтов знакомств в добрачном поведении населения. Не смотря на повсеместное распространение у населения, интернет-знакомства очень мало изучаются в социологии.

На начало 2020 года объем сайтов и сервисов знакомств более 8500, при этом их количество продолжает расти. Прогнозируемое количество пользователей сайта знакомств к 2020 году по всему миру - 310 миллионов. На одном из популярнейших сайтов знакомств Маmbа апреле 2020 года было 57 млн анкет, [4] а при посещение женского аккаунта из Саранска в апреле 2020 года можно было увидеть 38800 анкет пользователей-мужчин, находящихся в ближайшем расположении. По данным опроса компании HeadHunter 11\% россиян нашли спутника и супруга в интернете. [5] При этом пока не проведено серьезного социологического анализа этой сферы в России.

Сайты знакомств становятся все более распространенной формой добрачного поведения людей во всем мире. И становится актуальным изучение особенностей использования сайтов знакомств населением.

Под семейным поведением А. И.Антонов и В. М. Медков понимают все те специфические проявления социального поведения, которые делают возможным функционирование супружества-родительства-родства. Это, прежде всего брачное, репродуктивное и социализационное поведение - те типы семейного поведения, предопределяющие направленность на регистрацию брака, на рождение и социализацию детей в семье. [1] Если мы обратимся к сайтам знакомств, то абсолютно все сервисы среди целей, которые могут указать пользователи отмечают брак, создание семьи.

Знакомство на сайте - это первый этап брачного поведения, добрачное поведение. Как отмечает Л. Шнейдер, добрачное общение является первым этапом становления семьи [2, с. 56] Добрачное поведение и выбор брачного партнера - это очень важная сфера человеческих взаимоотношений. Оно во многом обусловливает характер будущего супружества. В свою очередь брачное поведение зависит от каждого из субъектов добрачных отношений.

В период добрачного общения мужчина и женщина узнают друг друга, обмениваются интересами и ценностями, проектируют совместную будущую жизнь. В современном мире большая часть общения происходит в Интернет и в социальных сетях и мессенджерах. Сайты знакомств взяли на себя функции знакомства, общения, узнавании друг друга, формирование первого впечатления, моделирование дальнейших отношений. Добрачное поведение и выбор брачного партнера - это очень важная сфера человеческих взаимоотношений. Социологи А. Г. Харчев и М. С. Мацковский отмечают, что добрачное поведение - понятие очень широкое. Оно во многом обусловливает характер будущего супружества. В свою очередь брачное поведение зависит от каждого из субъектов добрачных отношений. [6, с. 12]

Эмпирически доказано, что источником трудностей в семейной жизни могут стать особенности выбора партнера, характер добрачного поведения и предбрачного ухаживания, принятие решения о вступлении в брак.

К функциям добрачного периода Е. Зритнева относит следующие: накопление совместных переживаний и впечатлений; узнавание друг друга, уточнение и проверка принятого решения: проверяется функционально-ролевое соответствие партнеров (в настоящее время эта функция ослаблена, ей на смену пришло предбрачное 
сожительство, которое менее информативно); проектирование совместной жизни, моделирование будущей семьи. [3]

При этом общение на сайтах знакомств во многом облегчает пользователям эти задачи, поскольку все имеют возможности прямо и открыто заявлять о своих целях, интересах и предпочтениях, что в реальном общении не всегда возможно.

Многие популярные сайты знакомств своим пользователям предлагают обозначить цели знакомств. Некоторые из них относятся к добрачному поведению флирт, встречи (свидания), отношения, брак(семья). Пользователи также могут при выборе партнера по общению ставить фильтры и формировать таким образом для себя тот брачный круг, который соответствовал бы их интересам, сразу отсекая тех, чьи интересы не соотносятся их личными. Сайты знакомств при правильном их использовании могут стать весьма эффективным инструментом добрачного поведения. Они позволяют экономить время на знакомство и узнавание друг друга, формировать первое впечатление и обмениваться ценностями, расширять брачный круг.

В процессе добрачного поведения огромное значение придается брачному отбору и брачному выбору. А. И. Антонов под брачным отбором понимает процесс, в результате которого из совокупности возможных выборов брачного партнера выбирается тот, кто впоследствии станет мужем (женой). [1] Как уже отмечалось выше, сайты знакомств сегодня предоставляют огромные возможности выбора партнера по самым разным критериям: возраст, материальное положение, особенности проживания, наличие детей, вредные привычки (курение, алкоголь), география проживания и другие.

Таким образом, можно говорить о том, что в современном мире сайты знакомств включены в брачно-семейное поведение населения благодаря своим возможностям добрачного поведения и повсеместному распространению.

Как и любая информационная технология, сайты знакомств имеют свои преимущества и недостатки. Однако, считаем, как новую форму добрачного поведения необходимо изучать специфику использования сайтов знакомств людьми разного возраста, социального статуса и места проживания.

$$
* * *
$$

1. Антонов А. И. Социология семьи / А. И.Антонов, В. М.Медков. - М : Изд-во МГУ, 1996. - 304 c. [Электронный ресурс]. - Режим доступа: https://smolsoc.ru/images/referat/a1504.pdf

2. Гурко Т. А. Теоретические подходы к изучению семьи / Т. А. Гурко. - М. : Институт социологии PAH, 2010. $-210 \mathrm{c}$.

3. Зритнева Б. И. Семьеведение: учебное / Б. И. Зритнева: пособие. [Электронный ресурс] Режим доступа: http://thelib.ru/ books/elena_igorevna_zritneva /semevedenie_uchebnoe_posobieread.html

4. Рынок онлайн знакомств. Статистика Dating-сервисов за 2019 год. [Электронный ресурс]. - Режим доступа: https:/traff.ink/articles/rynok-onlajn-znakomstv-itogi-2019-goda/

5. Эксперты рассказали, какие знакомства чаще всего завершаются свадьбой. [Электронный ресурс]. - Режим доступа: https://ria.ru/20120706/693275007.html

6. Х Харчев А. Г. Социология семьи / А. Г. Харчев. - М.: ЦСП, 2003. -342 с. 